\title{
Przyroda wyzwaniem dla kultury Społeczności lokalne wobec obszarów chronionych Sprawozdanie z XIII ogólnopolskiej konferencji z cyklu „Ekologia Humanistyczna"
}

W dniach 16-17 października 2019 r. odbyła się kolejna ogólnopolska konferencja organizowana przez Centrum Ekologii i Ekofilozofii UKSW (dawny Instytut Ekologii i Bioetyki) przy współpracy Instytutu Badawczego Leśnictwa i Kampinoskiego Parku Narodowego. Patronami honorowymi konferencji byli: Senacka Komisja Środowiska, Ministerstwo Środowiska, Urząd Marszałkowski Województwa Mazowieckiego, Lasy Państwowe oraz Polskie Towarzystwo Leśne. Patronem medialnym konferencji był Klub Publicystów Ochrony Środowiska EKOS. W ramach konferencji zaprezentowano 27 referatów. Prelegenci reprezentowali 17 polskich ośrodków naukowo-badawczych oraz 8 innych instytucji (parki narodowe, fundacje, przedsiębiorstwa, muzea, szkoły i media). W sesji referatowej na Uniwersytecie Kardynała Stefana Wyszyńskiego w Warszawie wzięło udział ok. 115 uczestników, natomiast w sesji terenowej w Kampinoskim Parku Narodowym uczestniczyło 25 osób.

Pierwszy dzień konferencji miał charakter sesji referatowej, która odbywała się w kampusie UKSW przy ul. Wóycickiego 1/3 w Warszawie. Obrady przebiegały w równoległych sekcjach tematycznych: przyrodniczo-filozoficznej, społeczno-prawnej i edukacyjnej. Różnorodność i wysoki poziom merytoryczny wystąpień sprawiły, że uczestnicy z jednej strony z łatwością odnajdywali interesujące ich tematy, z drugiej zaś strony z trudnością dokonywali wyboru referatu, ze względu na równie interesujące propozycje prezentowane w tym

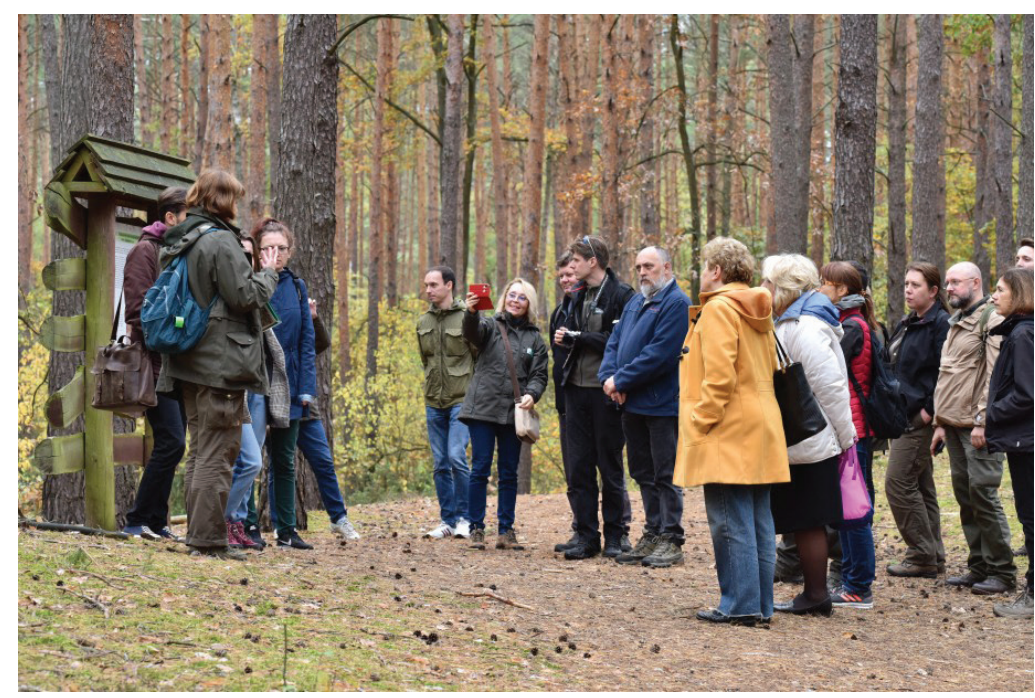


samym czasie w sąsiednich sesjach. Nie sposób w kilku zdaniach streścić i podsumować tak wielu i tak różnorodnych wystąpień, dlatego odsyłamy osoby zainteresowane do publikacji pokonferencyjnej. Na przełomie roku 2019/2020 ukaże się ona nakładem Instytutu Badawczego Leśnictwa i będzie zawierała przedstawione podczas konferencji referaty. Szczegółowy program konferencji, wraz z wieloma udostępnionymi przez prelegentów prezentacjami, jest dostępny na witrynie konferencyjnej - https://sites.google.com/view/13-eh-materialy/.

Drugi dzień konferencji miał charakter sesji terenowej, która odbywała się w Kampinoskim Parku Narodowym. Celem tej sesji było pokazanie funkcjonowania parku narodowego w warunkach silnej antropopresji, angażowanie społeczności lokalnej w zarządzanie obszarem, przeciwdziałanie i rozwiązywanie konfliktów, edukacja ekologiczna oraz udostępnianie obszaru. Program wyprawy obejmował wizytę w siedzibie KPN w Izabelinie, skąd uczestnicy udali się do wysuniętych na zachód części parku, obserwując unikatowe wydmy śródlądowe, torfowiska, łąki niżowe i olsy. Wyprawa zakończyła się w Ośrodku Dydaktyczno-Muzealnym Kampinoskiego Parku Narodowego w Granicy, gdzie po zapoznaniu się z jego ofertą dydaktyczna, przy ognisku podsumowano całość konferencji.

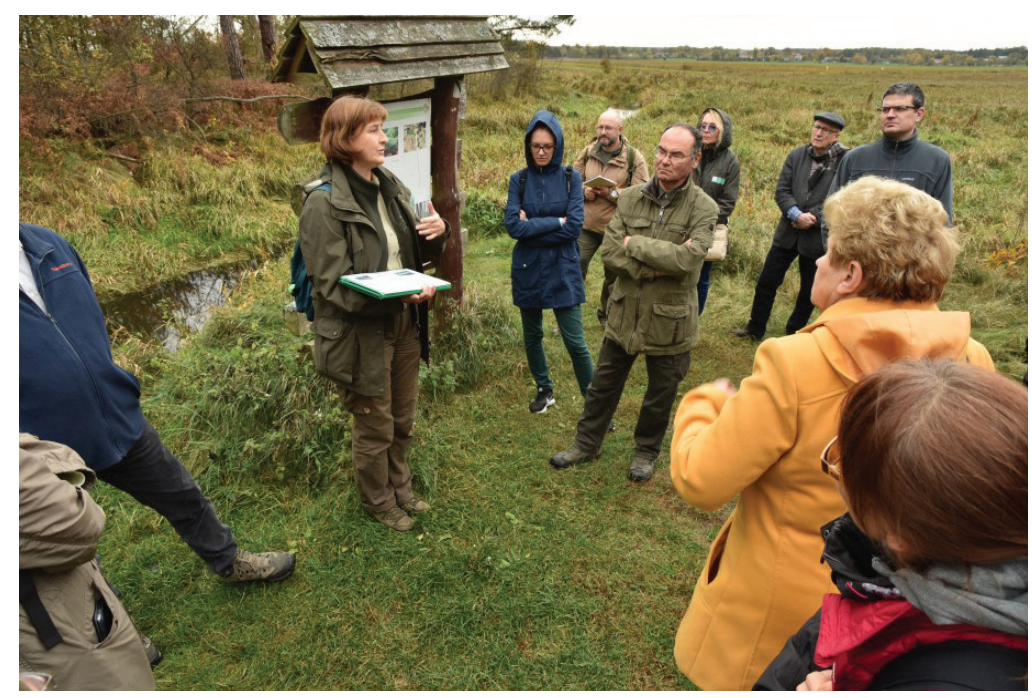

Ks. Ryszard Sadowski, SDB Centrum Ekologii i Ekofilozofii UKSW 